\title{
SKENARIO KEBIJAKAN INDUSTRI GULA UNTUK MENINGKATKAN KETERSEDIAAN GULA DIPASARAN DENGAN MENGGUNAKAN PENDEKATAN SISTEM DINAMIK
}

\author{
Agung Brastama Putra ${ }^{1}$, Erma Suryani ${ }^{2)}$ \\ ${ }^{1}$ Jurusan Sistem Informasi, Fakultas Teknik Industri, \\ Universitas Pembangunan Nasional Veteran (UPN) Jawa Timur \\ Jl. Rungkut Madya, Gunung Anyar Surabaya \\ ${ }^{2}$ Jurusan Sistem Informasi, Fakultas Teknologi Informasi, Institut Teknologi Sepuluh Nopember \\ Kampus Keputih, Sukolilo, Surabaya 60111 \\ Telp: (031) 5999944, Fax: (031) 5964965 \\ E-mail : agungTama@aol.com ${ }^{1)}$
}

\begin{abstract}
Sugar is one of the strategic commodities owned by Indonesia as a tropical country, sugar has been produced in 110 countries, such as Brazil, India, Australia, Thailand, China, and Cuba. Sugarcane land area reduced, supply of raw materials decreased, supply of raw materials also decreased, However, it can still be circumvented by holding sugarcane farmers, in the sugar system is dynamic dan flexible.

In this research focuses on the amount of inventories sugar in East Java and influencing variable in this research are land productivity, adding new land, land intensification, sugar production. That's all variable using to scenarios using to increase availability of sugar market. This paper use System Dynamic approach to solve complex problems how to increase sugar production.

In this research use scenario combination of intesification and extensification. The result of this paper are combination of intensification and extensification, results before the scenario is Land productivity 5/6 Ton/Ha, sugar production 1.020.411 Ton, and total sugar cane land area $200.386 \mathrm{Ha}$. And after using scenarios is sugar productivity increase to 9.7 Ton/Ha, sugar production into 2.061 .750 Ton, total sugar cane land area into $228.784 \mathrm{Ha}$.
\end{abstract}

\section{Abstrak}

Gula merupakan salah satu komoditas strategis yang dimiliki Indonesia sebagai negara yang terletak dikawasan tropis, gula telah diproduksi di 110 negara, diantaranya adalah Brazil, India, Australia, Thailand, China, dan Cuba. Luas lahan tebu juga makin berkurang. Hal ini berimbas pada pasokan bahan baku yang juga menyusut. Namun, hal ini masih bisa disiasati dengan mengikutsertakan petani tebu karena pada sistem pergulaan bersifat dinamis dan fleksibel.

Penelitian ini berfokus pada jumlah persediaan gula Jawa Timur dimana variabel yang mempengaruhinya adalah produktivitas lahan, lahan baru, intensifikasi lahan dan produksi gula. Variabel-variabel ini digunakan untuk pembuatan skenario persediaan gula di Jawa Timur yang bertujuan untuk meningkatkan persediaan gula sehingga swasembada gula dapat tercapai. Penelitian ini menggunakan sistem dinamik untuk menyelesaikan permasalahan peningkatan produksi gula.

Skenario yang terdapat pada penelitian ini adalah penggabungan extensifikasi lahan dan intensifikasi lahan. Hasil penelitian ini sesuai dengan scenario yang dibangun yaitu hasil produktivitas mencapai 5-6 Ton/Ha, produksi gula sebesar 1.020.411 Ton, luas lahan 200.386 Ha, dan setelah dilakukan skenario hasilnya adalah produktivitas lahan naik menjadi 9,7 Ton/Ha, produksi gula menjadi 2.061.750 Ton, luas lahan tebu menjadi 228.784 Ha.

Kata kunci: buffer stock management, industri gula, ketersediaan gula, sistem dinamik.

\section{PENDAHULUAN}

Gula merupakan salah satu komoditas strategis yang dimiliki Indonesia sebagai negara yang terletak di kawasan tropis, komoditas strategis menurut PASKOMNAS (Pasar Komoditi Nasional) adalah barang/jasa yang mempunyai pengaruh besar terhadap perekonomian, atau dengan kata lain produk yang rentan menjadi permainan kartel. Menurut Simatupang komoditas strategis adalah barang/jasa yang memiliki nilai penting untuk hajat hidup orang banyak, baik dari segi lapangan kerja, maupun jaminan perolehan pangan yang cukup, perlindungan, dan dinamisasi kehidupan desa secara berkelanjutan, serta preservasi dan stabilisasi sosial-politik yang sesungguhnya merupakan tujuan utama 
Putra, dkk., Skenario Kebijakan Industri Gula untuk Meningkatkan Ketersediaan Gula..

pembangunan pertanian. Mengacu pada Undang-Undang Nomor 7 Tahun 1996 tentang komoditas pangan strategis dan KEPRES nomor 57 tahun 2004, pemerintah Indonesia menetapkan gula sebagai barang dalam pengawasan. Sejak tahun 2000 pemerintah menunjuk PT. Perkebunan Nusantara (PTPN) IX, PTPN X dan PTPN XI sebagai importer terdaftar, dengan ditunjuknya PTPN ini maka, kewenangan pemerintah terhadap PTPN adalah memperbaiki harga gula domestik dimana petani dan industri yang berada dibawah PTPN di pacu untuk meningkatkan produksi sehingga diharapkan indonesia tidak lagi bergantung pada impor gula (Zaini, 2008).

Mengutip keterangan Kepala Urusan Umum PTPN IX, Djarot Iryawan produksi di PTPN memang terus turun. Hal ini karena kondisi mesin yang berusia tua. Tidak hanya itu, luas lahan tebu juga makin berkurang. Hal ini berimbas pada pasokan bahan baku yang juga menyusut. Namun, hal ini masih bisa disiasati dengan mengikutsertakan petani tebu rakyat. Menurut data BPS ketersediaan gula nasional semakin lama semakin mengalami penurunan sedangkan laju pertumbuhan penduduk semakin lama semakin meningkat. Data terakhir (2011) dari luas lahan perkebunan tebu nasional sebesar 473,923 ha dengan pertumbuhan setiap tahun sebesar 8,226 ha antara tahun 1967 sampai tahun 2011. Gambar 1 menjelaskan tentang pertumbuhan luas lahan tebu nasional.

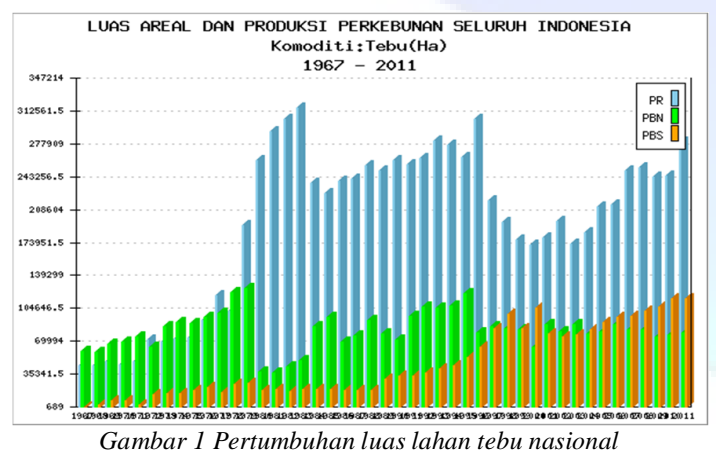

Dengan PR adalah lahan milik petani, PBN adalah lahan milik pemerintah sedangkan PBS adalah lahan milik pribadi atau personal. Luas area lahan tebu setiap tahun bisa turun atau ada peningkatan tapi di sisi lain peningkatan jumlah lahan tebu tersebut bisa menambah atau mengurangi jumlah hasil produksi tebu mentah menjadi gula kristal (Tabel 1), kenaikan dan penurunan produksi dapat disebabkan oleh lingkungan, gulma, hama, penyakit dan curah hujan (iklim/ cuaca) (Ferraro, dkk, 2009).
Tabel 1. Data Statistik Luas lahan Tebu di Jawa Timur

\begin{tabular}{ll}
\hline Year & Land Area in East Java (Ha) \\
\hline 2004 & 150111 \\
2005 & 169338 \\
2006 & 183229 \\
2007 & 204134 \\
2008 & 198599 \\
2009 & 198944 \\
2010 & 200131 \\
\hline
\end{tabular}

Tabel 2. Populasi di Jawa Timur

\begin{tabular}{ll}
\hline Year & Total \\
\hline 2008 & 36937660 \\
2009 & 37222628 \\
2010 & 37510732 \\
2011 & 37802044 \\
\hline
\end{tabular}

Tabel 3. Produksi Gula di Jawa Timur

\begin{tabular}{ll}
\hline Year & Total (Toon) \\
\hline 2007 & 1342195 \\
2008 & 1302616 \\
2009 & 1107843 \\
2010 & 1020411 \\
\hline
\end{tabular}

Dalam analisa langsung di lapangan padasistem tanam tebu telah disampaikan informasi yang menjelaskan mengenai tren dalam produktivitas (Ellis, dkk., 2001) atau perubahan akibat lingkungan atau variabilitas iklim (Russell dkk., 1991; \& Lawesetal, 2004). Produktivitas CCS (Commercial Cane Sugar) mengalami penurunan apabila hasil panen tebu basah (Lawes, RA et All, 2005). Parameter lainnya, curah hujan dalam 30 hari sebelum panen kemungkinan untuk mempengaruhi CCS. Curah hujan dapat mempengaruhi tingkat akumulasi sukrosa dalam tangkai dan akan cenderung meningkatkan tingkat hidrasi (Robertson et al., 1999).

Javalagi (2007) mengungkapkan dalam hasil penelitiannya bahwa kemajuan teknologi merupakan komponen penting dalam industri gula terutama dalam penanganan stock dan distribusi. Banyak perusahaan yang berhasil dalam penanganan stock dan distribusi dengan ditunjang oleh teknologi dan manajemen yang baik (Goldsby dkk., 2006). Ketersediaan informasi sangat penting dalam industri gula, karena itu Java memasukkannya dalam bidang kemajuan teknologi, hal ini didukung oleh penelitian dari (Lawes, RA \& Lawn. 2005) yang menyatakan bahwa informasi yang disediakan industri dapat memberikan wawasan berharga untuk sistem produksi tebu dan membantu pengambilan keputusan dalam industri. 
Perubahan perilaku sistem terhadap waktu, dinamika sistem yang kompleks, adanya umpan balik dan umpan balik tersebut memberikan informasi terbaru tentang keadaan sistem yang kemudian akan menghasilkan keputusan (Suryani, 2010) dari karakteristik tersebut maka penelitian ini menggunakan pendekatan sistem dinamik untuk meningkatkan persediaan gula di Jawa Timur.

\section{METODOLOGI}

Menurut Erma Suryani dalam buku "pemodelan dan simulasi" (2006:1) model merupakan representasi sistem dalam kehidupan nyata yang menjadi fokus perhatian dan menjadi pokok permasalahan. Pemodelan dapat didefinisikan sebagai proses pembentukan model dari sistem tersebut dengan menggunakan bahasa formal tertentu. Menurut Andersson dan Karlsson (2001:17) sebuah model adalah abstraksi dari objek nyata atau sistem, dan pemodelan sistem berarti menangkap dan abstrak komponen sistem, hubungan dan perilaku, sesuai dengan tujuan model (Gambar 2).

\subsection{Model Sistem Dinamik}

Menurut Sterman (2000), pendekatan sistem dinamik yang kompleks memerlukan model formal dan metode simulasi untuk menguji, meningkatkan dan merancang kebijakan baru. Menurut Erma Suryani dalam buku "pemodelan dan simulasi" (2006:63) simulasi sistem dinamik merupakan simulasi kontinyu yang dikembangkan oleh Jay Forrester (MIT) tahun 1960-an, berfokus pada struktur dan perilaku sistem yang terdiri antar variabel dan loop feedback (umpan balik). Hubungan dan interaksi antar variabel dinyatakan dalam diagram kausatik. Proses umpan balik dapat dikelompokkan menjadi dua bagian yaitu (Suryani, 2006:63-64) :

1. Umpan balik positif

Jenis umpan balik ini menciptakan proses pertumbuhan, dimana suatu kejadian dapat menimbulkan akibat yang akan memperbesar kejadian berikutnya secara terus menerus. Umpan balik ini dapat menyebabkan ketidakstabilan, ketidakseimbangan, serta pertumbuhan yang kontinyu. Contoh: sistem pertumbuhan penduduk.

2. Umpan balik negatif

Jenis umpan balik ini berusaha menciptakan keseimbangan dengan memberikan koreksi agar tujuan dapat dicapai. Contoh: sistem pengatur suhu ruangan.

Menurut Sterman (2000), terdapat lima tahapan dalam mengembangkan model sistem dinamik seperti terlihat dalam yaitu:

\section{Step 1: Problem articulation:}

Pada tahap ini, kita perlu menemukan masalah yang sebenarnya, mengidentifikasi variabel kunci dan konsep, menentukan horison waktu dan mencirikan masalah secara dinamis untuk memahami dan merancang kebijakan menyelesaikannya.

\section{Step 2: Dynamic hypothesis:}

Pembuat model harus mengembangkan sebuah teori tentang bagaimana masalah tersebut muncul. Dalam step ini, perlu dikembangkan diagram causal loop yang menjelaskan hubungan kausal antara variabel dan mengkonversi diagram causal loop ke dalam diagram flow.

\section{Step 3: Formulation:}

Untuk menentukan model sistem dinamik, setelah mengubah diagram causal loop ke dalam diagram flow, selanjutnya harus menerjemahkan deskripsi sistem menjadi level, rates dan membuat persamaan/auxiliary equations. Untuk mengestimasi sejumlah parameter, hubungan perilaku, dan kondisi awal. Pembuatan equations akan mengungkapkan kesenjangan dan inkonsistensi yang harus diperbaiki dalam deskripsi sebelumnya.

\section{Step 4: Testing:}

Tujuan pengujian adalah untuk membandingkan perilaku simulasi model terhadap perilaku aktual dari sistem.

\section{Step 5: Policy Formulation and evaluation:}

Sejak pembuat model mengembangkan keyakinan dalam struktur dan perilaku model, pemodel dapat memanfaatkan model yang valid untuk merancang dan mengevaluasi kebijakan bagi perbaikan. Interaksi kebijakan yang berbeda juga harus diperhatikan, karena sistem nyata sangat nonlinear dan dampak kombinasi kebijakan biasanya tidak berupa dampaknya saja.

\subsection{Buffer Stock Manajemen}

Menurut Cognizant perbedaan antara buffer stock dan safety stock adalah buffer stock mencegah produsen dari kemungkinan tidak dapat memenuhi permintaan pelanggan sedangkan safety stock membantu produsen untuk memenuhi variasi dalam penyediaan bahan baku. Menurut Jensen et al. (1991) dalam Puijman (2011), tujuan utama dari buffer stock adalah untuk melindungi rantai pasokan terhadap kegagalan dalam tahapan di pabrik dalam proses produksi dalam memenuhi permintaan pelanggan dari hulu dan hilir. Implementasi buffer stock sudah diterapkan dalam stabilisasi harga sebagai contohnya dalam penelitian Swaray (2011) menunjukkan bahwa dengan adanya 
Putra, dkk., Skenario Kebijakan Industri Gula untuk Meningkatkan Ketersediaan Gula..

buffer stock dapat menstabilkan harga dan pendapatan dari produsen kakao.

Pada tahap pengumpulan data dilakukan dengan mengamati kondisi di lapangan kemudian mengambil data yang digunakan sebagai variabel yang signifikan maupun variabel pembantu yang saling berpengaruh untuk pemodelan sistem yang akan disimulasikan. Data yang dibutuhkan tersebut diperoleh dengan berbagai cara, yaitu: pengamatan langsung dan wawancara dengan para stakeholder serta dari dokumentasi yang telah ada seperti data produksi gula, data produktivitas lahan, data populasi, data luas lahan.
Pada tahap kajian pustaka dilakukan dengan mencari literatur pada buku text, artikel pada jurnal yang relevan dan melihat dokumentasi laporan kegiatan dan program kerja perpustakaan.

Langkah awal pada pemodelan sistem adalah pembuatan model konseptual dengan digambarkan melalui causal loop diagram atau diagram kausal (Gambar 3). Diagram kausal ini digunakan untuk visualisasi sistem secara umum yang nantinya disimulasikan dengan metode sistem dinamik melalui komponen yang terlihat. Komponen inilah yang menjadi variabel, parameter dan konstanta yang saling tergantung dan mempengaruhi pada perilaku sistem.

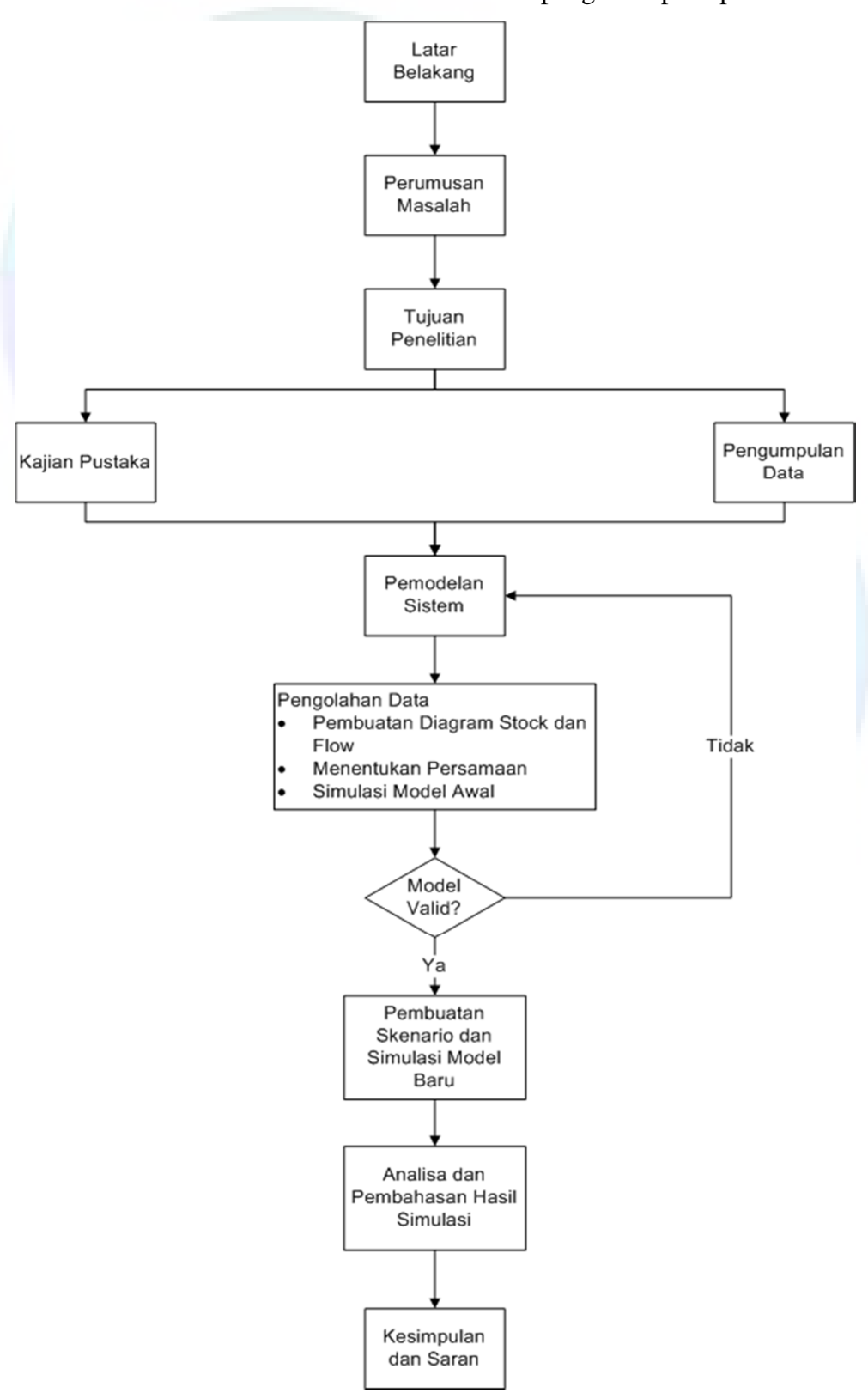

Gambar 2. Metodologi Penelitian 
Pada tahap ini, model konseptual yang dilakukan sebelumnya dengan diagram kausal, diterjemahkan menjadi model sistem dinamik yang digambarkan melalui diagram stock dan flow yang terbentuk melalui empat komponen, yaitu: sistem, umpan balik, level dan rate. Kemudian menentukan persamaan dari setiap variabel sebagai formulasi pada model dilakukan dengan cara memahami dan menguji konsistensi model apakah sudah sesuai dengan tujuan dan batasan sistem yang dibuat.

Verifikasi dilakukan dengan melakukan pengecekan terhadap model dan unit pada model dengan menggunakan fasilitas pada Vensim. Validasi model dilakukan dengan dua cara pengujian, yaitu validasi model dengan statistik uji perbandingan rata-rata (mean comparison) dan validasi model dengan uji perbandingan variasi amplitudo (\% error variance) (Barlas, 1989).

a. Uji perbandingan rata-rata (Mean Comparison)

(3.1) $E 1=\frac{\lfloor\bar{S}-\bar{A}\rfloor}{\bar{A}}$

$\bar{S}=n i l a i_{-} r a t a-r a t a \_h a s i l \_s i m u l a s i$

$\bar{A}=$ nilai_rata-rata_data Dimana model dianggap valid bila $\mathrm{E} 1 \leq 5 \%$

b. Uji perbandingan variasi amplitudo ( \% error variance)

(3.2) $E 2=\frac{|S s-S a|}{S a}$

Ss $=$ standard deviasi hasil simulasi
$\mathrm{Sa}=$ standard deviasi data

Dimana model dianggap valid bila E2 $\leq$ $30 \%$

\subsection{Perlakuan Model dengan Skenario}

Pada tahap ini, model yang telah dibuat diberi beberapa perlakuan model dengan membuat skenario untuk memberikan meningkatkan ketersediaan gula dipasaran

\subsection{Analisa dan Pembahasan Hasil Simulasi}

Membuat analisa hasil simulasi dari pengembangan model awal sistem yang telah dibuat, kemudian menganalisa hasil simulasi model baru yang dibuat dengan skenario yang telah dibuat.

Dari analisa dan pembahasan yang telah dilakukan akan disimpulkan hasil yang diperoleh dan kemudian diberikan saran yang berkaitan engan pengembangan perpustakaan dan penelitian lanjutan.

\subsection{Stock Flow Diagram Luas Lahan}

Luas lahan merupakan salah satu faktor yang sangat penting dalam penelitian ini, dengan mengetahui luas lahan yang dimiliki oleh para stakeholder (Pemerintah, Petani dan Swasta) maka dapat digunakan untuk mengetahui produktivitas lahan. Gambar 4 ini adalah sub model dari masing-masing stakeholder. Gambar grafik pada Gambar 5 menunjukkan bahwa sejak tahun 2000 sampai 2010 mengalami peningkatan secara signifikan, terutama pada tahun 2004 sampai 2007.

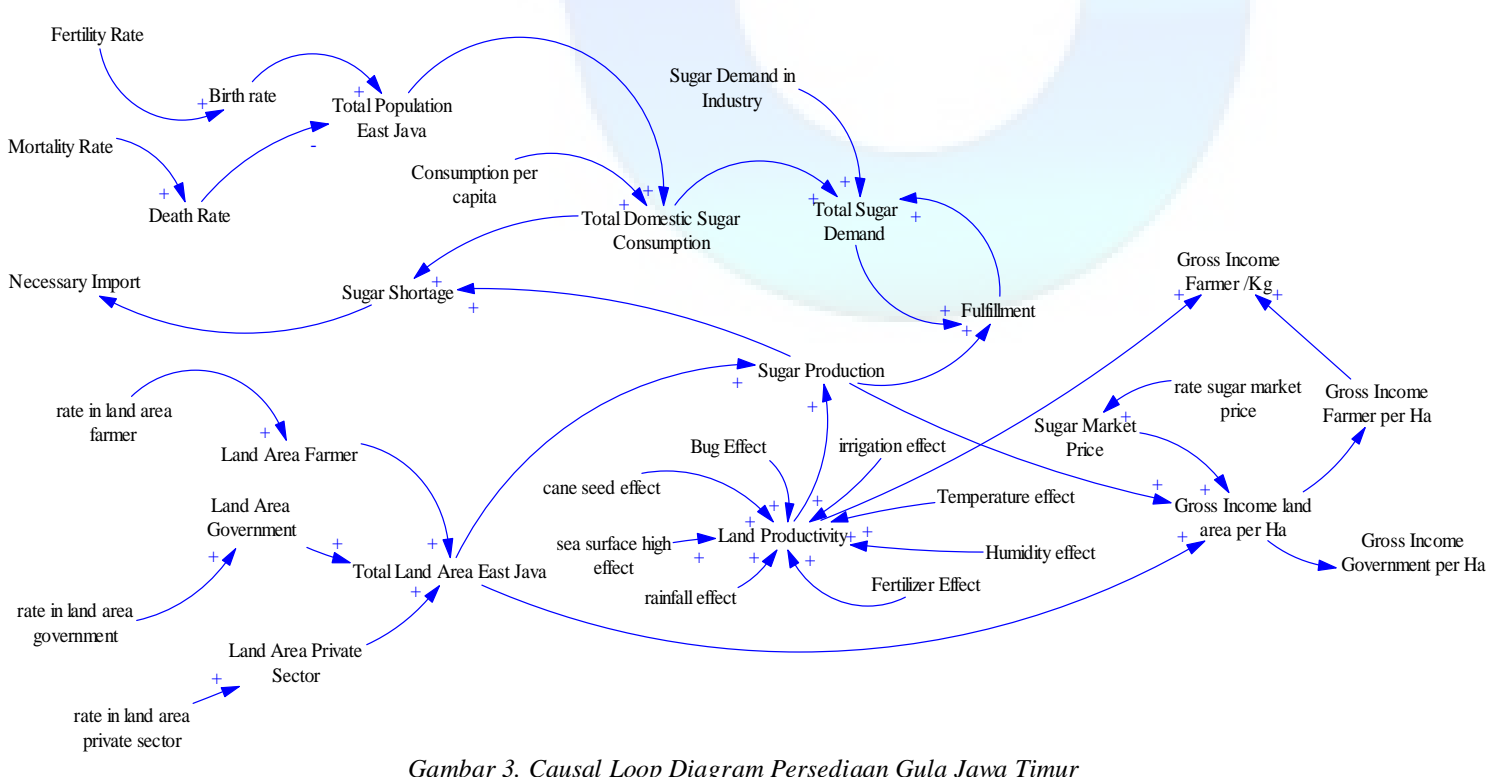


Putra, dkk., Skenario Kebijakan Industri Gula untuk Meningkatkan Ketersediaan Gula..

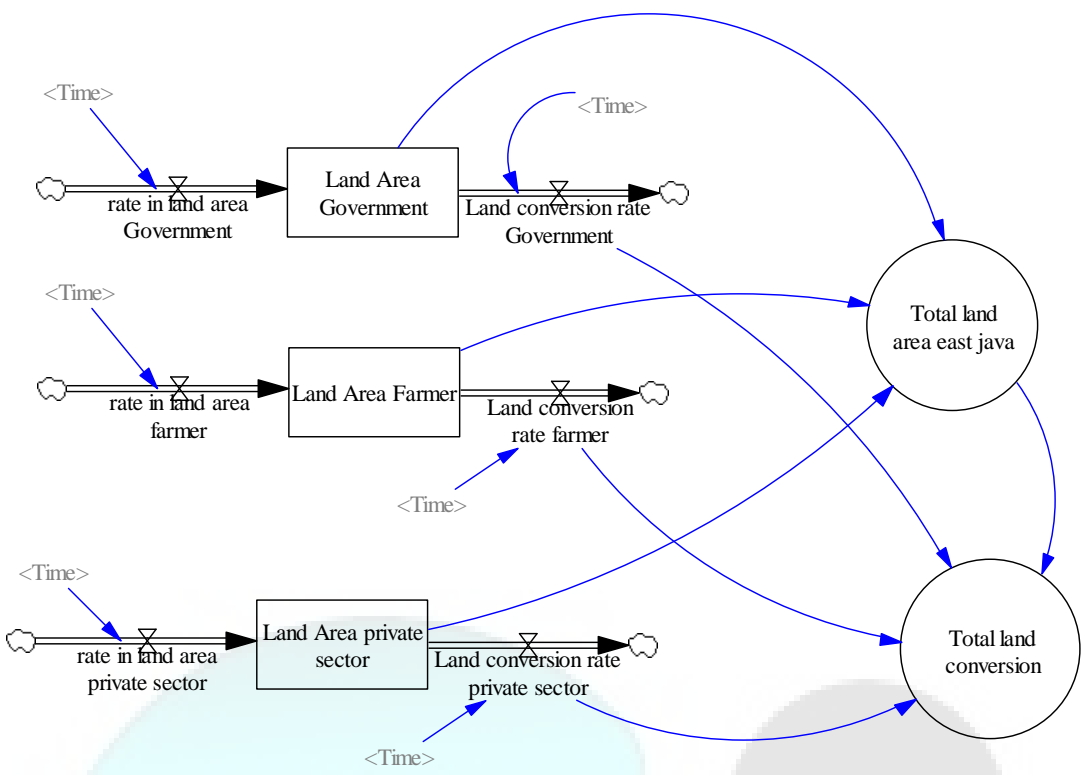

Gambar 4. Diagram Flow Luas Lahan Tebu di Jawa Timur

Total land area east java

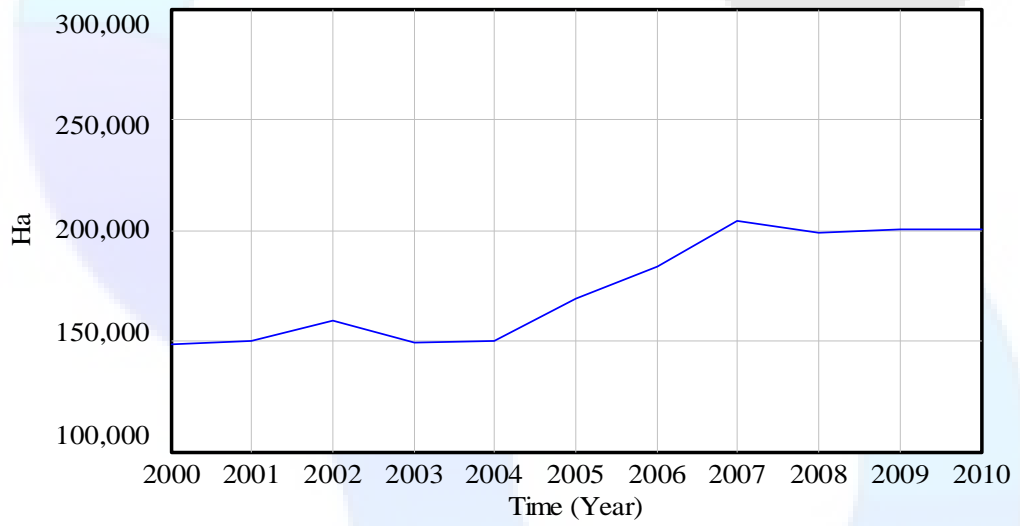

Total land area east java : Populasi_Surabaya

Gambar 5. Grafik Luas lahan Tebu di Jawa Timur

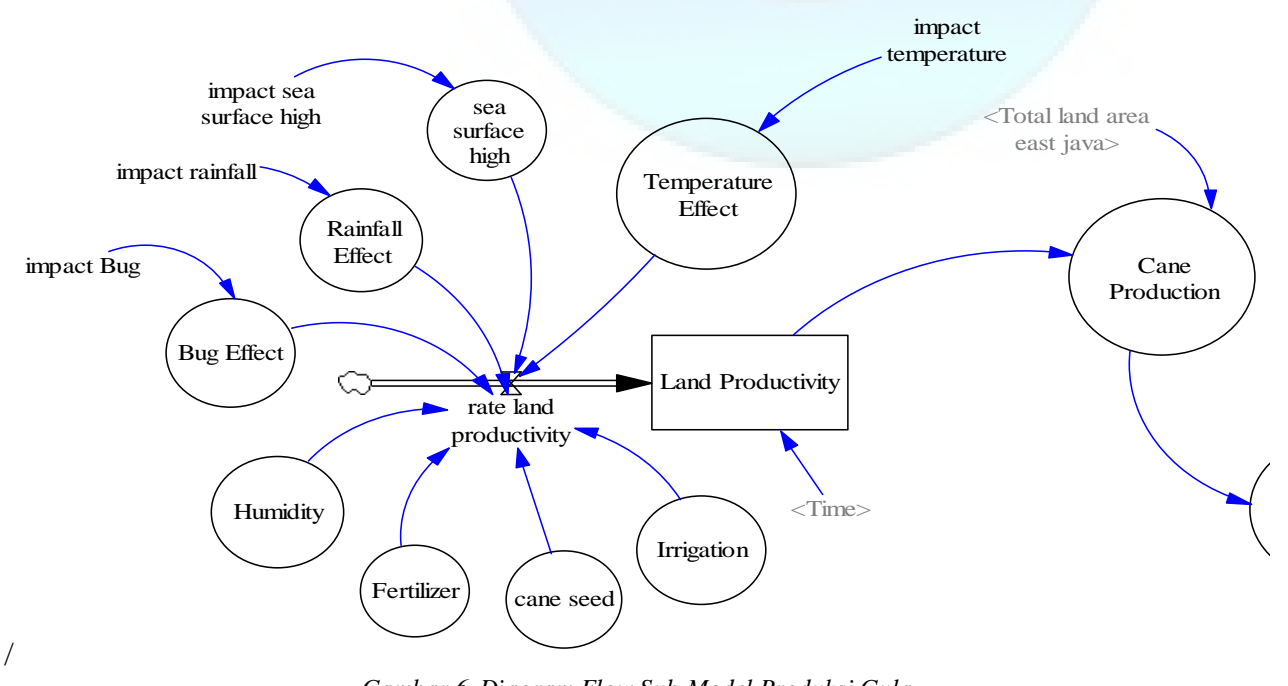

Gambar 6. Diagram Flow Sub Model Produksi Gula 


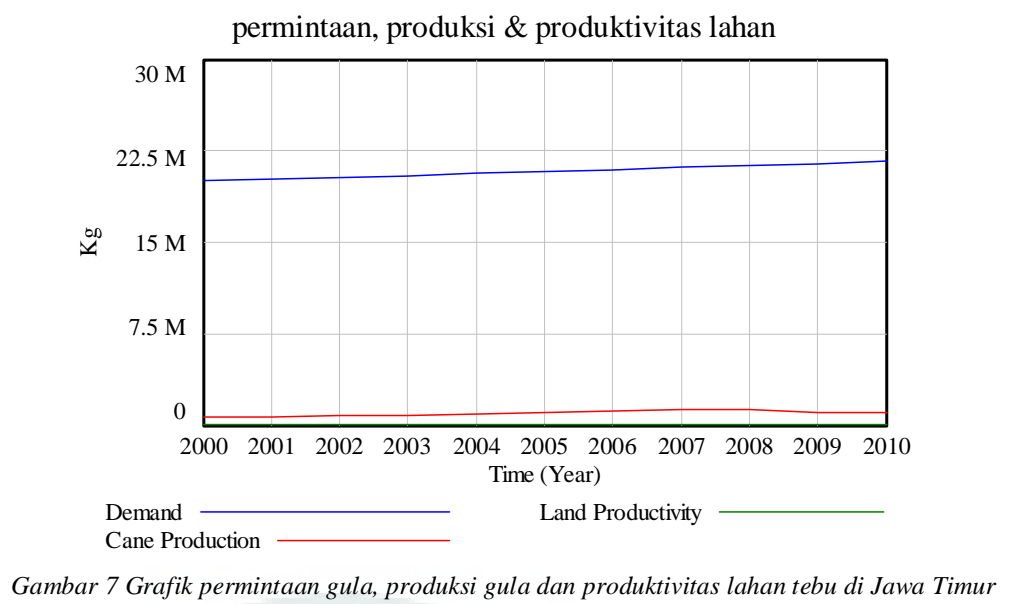

\subsection{Stock Flow Diagram Produksi dan Produktivitas Lahan}

Dengan permintaan terhadap gula semakin meningkat maka hasil produksi gula harus diperbanyak, sehingga mampu memenuhi permintaan gula domestik yang ada, produksi gula tidak bisa lepas dengan produktivitas lahan, semakin banyak per Ha lahan menghasilkan maka produktivitas akan naik dan produksi gula akan ikut meningkat. Gambar 6 adalah diagram flow dari sub model produksi

Gambar grafik 7 menunjukkan pergerakan hasil produksi gula mulai tahun 2000-2010. Serta perbandingan kenaikan dan penurunan produktivitas lahan pada produksi gula, terhadap pemenuhan permintaan.

\subsection{Validasi}

Validasi model dilakukan dengan dua cara, yaitu validasi model dengan statistik uji perbandingan rata-rata (mean comparison) dan validasi model dengan uji perbandingan variasi amplitudo (\% error variance) (Barlas, 1989).

Validasi Data Luas Lahan

Dari nilai rata-rata data riil sebesar 191165,2 Ha dan standart deviasi untuk data riil sebesar 23551,92624 Ha sedangkan untuk rata-rata data model simulasi adalah 191332,6313 Ha dan untuk standart deviasi model simulasi adalah 23749,43524 Ha dengan menggunakan model validasi dari Yaman Barlas maka ditentukan E1 dan E2, dimana E1 ini adalah nilai rata-rata dari data riil dikurangi dengan nilai rata-rata data model simulasi dibagi dengan nilai rata-rata data riil, dan nilai E1 tidak boleh lebih dari sama dengan 5\%. Nilai E1 untuk sub model luas lahan adalah 0,000875846 kemudian dikalikan $100 \%$ maka hasilnya $0,087584588 \%$ jadi untuk E1 dinyatakan valid (Gambar 8-10).
Sedangkan untuk E2 adalah nilai standart deviasi model dikurangi dengan nilai standart deviasi data riil dibagi dengan nilai standart deviasi data riil dan nilai E2 tidak boleh lebih dari sama dengan $30 \%$. Nilai E2 untuk sub model populasi adalah 0,008386108 kemudian dikalikan dengan $100 \%$ maka hasilnya adalah 0,83861082\% jadi E2 dinyatakan valid.

Sehingga karena $\mathrm{E} 1<=5 \%$ dan $\mathrm{E} 2<=30 \%$ maka sub model luas lahan bisa dinyatakan bahwa sub model ini valid atau menggambarkan kondisi sistem nyata. Berikut ini adalah perbandingan grafik antara data riil dengan data sub model luas lahan secara keseluruhan.

Validasi Data Produksi dan produktivitas

Perbandingan E1 dari data riil dengan data simulasi sebesar 0,007619658 kemudian hasil ini dikalikan $100 \%$ untuk menunjukkan bahwa nilai $\mathrm{E} 1<=5 \%$, sehingga hasil $\mathrm{E} 1$ setelah dikalikan $100 \%$ sebesar 0,761965809\%, hal ini berarti E1 valid. Sedangkan untuk E2 dari data riil dengan data simulasi sebesar 0,021204379 kemudian dikalikan $100 \%$ untuk menunjukkan bahwa nilai $\mathrm{E} 2<=30 \%$, sehingga hasil E2 setelah dikalikan dengan $100 \%$ adalah 2,120437948\%, hal ini berarti E2 dikatakan valid karena kurang dari $30 \%$, Sehingga karena $\mathrm{E} 1<=5 \%$ dan $\mathrm{E} 2<=30 \%$ maka sub model produksi bisa dinyatakan bahwa sub model ini valid atau menggambarkan kondisi sistem nyata.

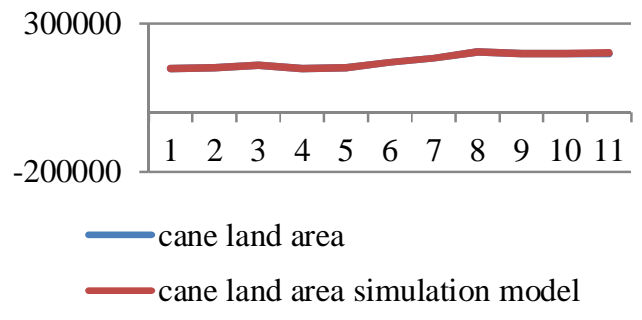

Gambar 8. Grafik Perbandingan luas lahan antara data riil dengan data model simulasi 
Putra, dkk., Skenario Kebijakan Industri Gula untuk Meningkatkan Ketersediaan Gula..

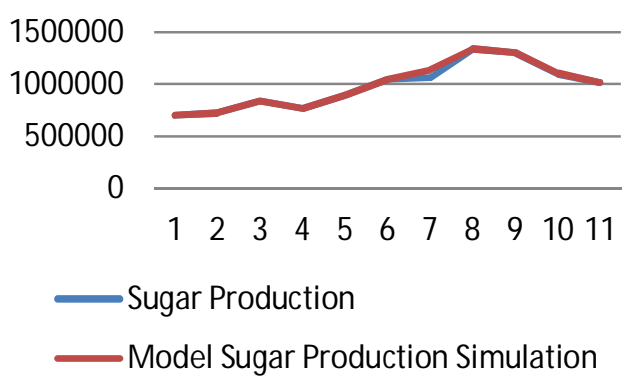

Gambar 9 Grafik Perbandingan Sub Model Produksi antara data riil dengan data model simulasi

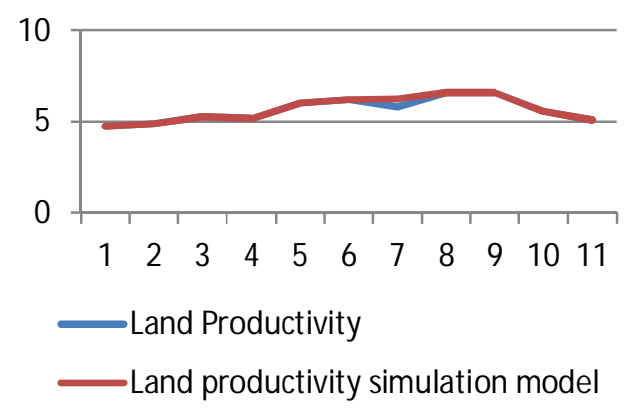

Gambar 10 Grafik Perbandingan Sub Model Produktivitas lahan antara data riil dengan data model simulasi.

\section{HASIL dan PEMBAHASAN}

Hasil produktivitas lahan setelah dilakukan intesifikasi lahan yaitu dengan memperbaiki dan merawat pengolahan lahan dari segi pemupukan, bibit tebu yang sesuai dan melakukan pengairan yang cukup untuk tanaman tebu sehingga terjadi peningkatan terhadap hasil tetes tebu/rendemen.

Sebelumnya sistem irigasi petani tebu dengan cara langsung menggenangi lahan dengan air tanpa melakukan pengolahan kebutuhan air yang masuk pada lahan, pemberian air yang cukup dilakukan sejak penggarapan tanah sampai mendapat curah hujan yang memenuhi syarat. Pemberian air pada kebun dilakukan pada saat dan dengan jumlah yang tepat, terutama menjelang penggarapan tanah, menjelang dan sesudah penanaman, dan selama pemeliharaan sampai 4-5 bulan yang meliputi penyiraman rutin tanaman yang masih muda dan setiap selesai pemupukan, pemberian air disesuaikan dengan kondisi tanah dan curah hujan dan kebutuhan tanaman (deptan.go.id) (Tabel 4).

Benih merupakan salah satu faktor yang sangat berpengaruh terhadap produksi, Untuk mendapatkan benih tebu unggul bermutu, diperlukan kebun benih tebu dengan menggunakan benih yang memenuhi syarat, sekurang-kurangnya memiliki empat kriteria yaitu: 1) Benih yang digunakan memiliki asal-usul yang jelas dan benar varietasnya; 2) Benih yang digunakan memiliki tingkat kemurnian yang tinggi $(\geq 95 \%) ; 3)$ Benih yang digunakan adalah benih yang sehat; 4) Benih yang digunakan berasal dari tanaman yang tumbuh normal. Kalau tanpa intensifikasi lahan $1 \mathrm{Ha}$ lahan tebu menghasilkan 5-6 Ton/Ha maka dengan intensifikasi lahan bisa menghasilkan 8-9 Ton/Ha (Lampiran 1). Berikut ini gambar grafik tentang perbandingan hasil skenario produktivitas lahan setelah intesifikasi lahan dan sebelum intesifikasi lahan. Dengan meningkatnya produktivitas lahan maka hasil produksi gula akan ikut meningkat. Perbandingan peningkatan hasil produksi gula (Lampiran 1) dapat dilihat dalam grafik produksi gula sebelum dilakukan intensifikasi lahan dan sesudah intensifikasi lahan (Gambar 11-13).

\subsection{Extensifikasi Lahan}

Hasil dari skenario total luas lahan setelah dilakukan extensifikasi lahan yaitu dengan penambahan lahan baru atau membuka lahan baru adalah terjadi peningkatan dalam bahan baku jumlah produksi yang digiling dan luas lahan tebu semakin luas sehingga hasil produksi akan meningkat (lampiran 1)

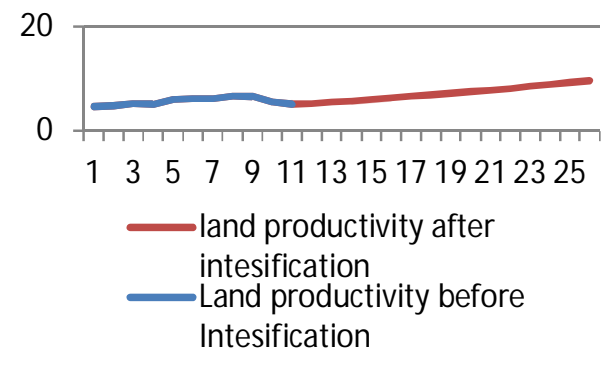

Gambar 11 Grafik hasil skenario produktivitas lahan setelah intesifikasi lahan dan sebelum.

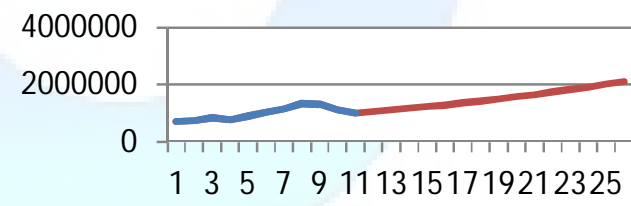

Sugar production after intesification

—Sugar production before intensification

Gambar 12 Grafik produksi gula sebelum dilakukan intensifikasi lahan dan sesudah intensifikasi lahan.

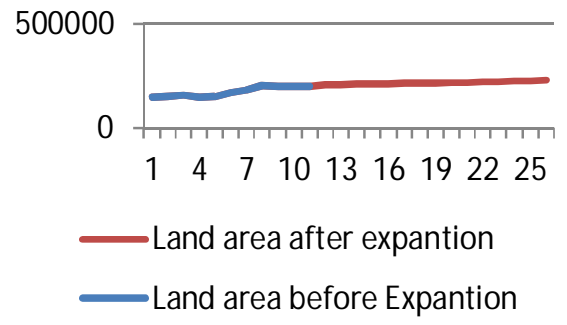

Gambar 13 Grafik skenario setelah penambahan luas lahan dan sebelum penambahan luas lahan. 


\subsection{Gabungan Intesifikasi dan Extensifikasi}

Hasil skenario adalah menggabungkan antara skenario intensifikasi dan extensifikasi sehingga terjadi peningkatan bahan baku, produktivitas lahan semakin baik, produksi gula meningkat dan kebutuhan akan import gula akan semakin menurun. Gambar 14 diagram flow penggabungan intesifikasi dan extensikasi. Berikut ini ringkasan skenario dari hasil pembahasan yang diambil dari base model (detil pada lampiran) dan model simulasi.

\section{KESIMPULAN DAN SARAN}

Berdasarkan hasil dari pengolahan data serta analisa dan pembahasan yang dilakukan maka dapat diambil simpulan antara lain sebagai berikut:

1. Proses pengembangan model memerlukan pemahaman yang mendalam terhadap kondisi real yang ada, dan informasi yang lengkap sehingga model yang dibuat dapat meng- gambarkan kondisi real (mewakili keadaaan sistem saat ini).

2. Dalam pengembangan dengan menggunakan sistem dinamik, sistem umpan balik memegang peranan penting, dimana dengan sistem umpan balik menyatakan bagaimana variabel mempengaruhi variabel yang lain.

3. Pada penelitian ini variabel yang berpengaruh terhadap persediaan adalah produktivitas lahan, produksi gula, luas lahan, land conversion. Sedangkan untuk variabel produktivitas lahan variabel yang mempengaruhi adalah bibit tebu, pemupukan, irigasi lahan, sumber daya manusia, temperatur/suhu udara, curah hujan, ketinggian lahan dari permukaan laut, hama dan untuk variabel luas lahan variabel yang mempengaruhi adalah luas lahan sebelum penambahan, luas lahan setelah penambahan.

4. Dari skenario menggabungkan extensifikasi dan intensifikasi produktivitas lahan menjadi 9,7Ton/Ha, produksi gula menjadi 2.061.750 Ton pada akhir periode simulasi tahun 2025 .

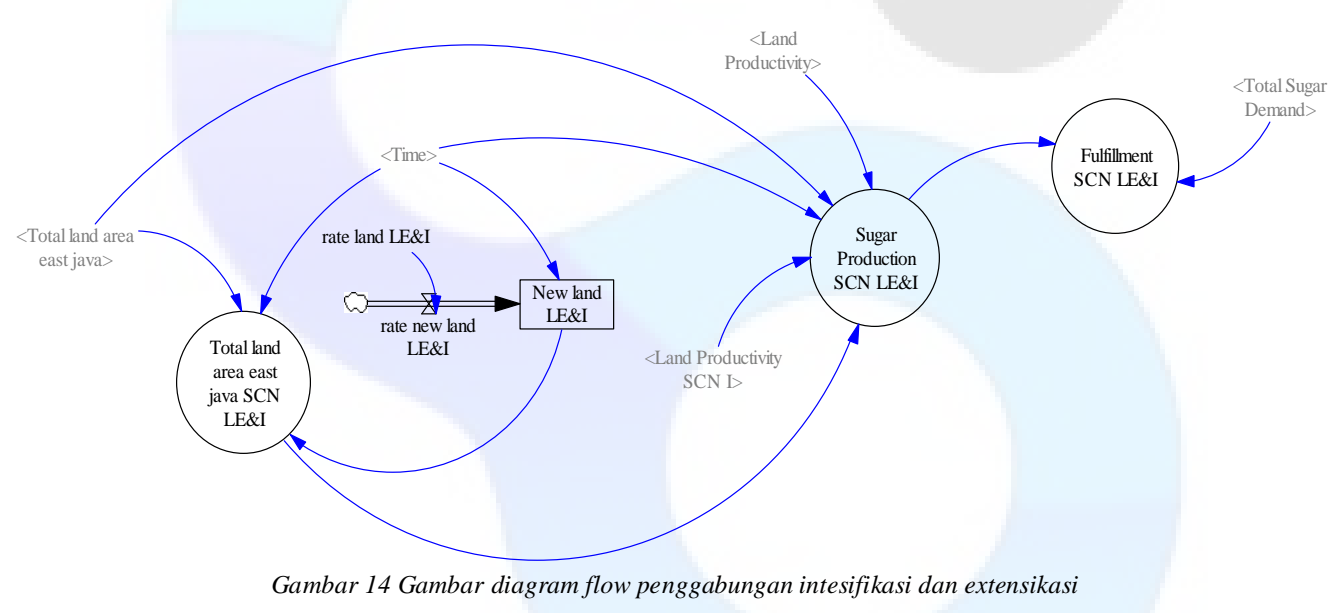

Tabel 4. Ringkasan Skenario

\begin{tabular}{|c|c|c|}
\hline Jenis Skenario & Pengembangan & Hasil \\
\hline \multirow{12}{*}{$\begin{array}{l}\text { Skenario } \\
\text { Gabungan } \\
\text { Intensifikasi } \\
\text { dan } \\
\text { Extensifikasi }\end{array}$} & Sebelum skenario & - $\quad$ Produktivitas lahan sebesar 5-6 Ton/Ha pada tahun 2010. \\
\hline & gabungan & - Luas Lahan 200.386 Ha pada tahun 2010 \\
\hline & Intensifikasi dan & - $\quad$ Produksi gula pada tahun 2010 sebesar 1.020.411 Ton \\
\hline & Extensifikasi & - Kebutuhan import sebesar 1.145.130 Ton. \\
\hline & & - $\quad$ Harga gula pada tahun 2010 sebesar Rp 10.996 \\
\hline & Setelah skenario & - $\quad$ Produktivitas lahan sebesar 8-9 Ton/Ha. \\
\hline & gabungan & - Luas lahan pada tahun 2011 menjadi $207.989 \mathrm{Ha}$ dan \\
\hline & Intensifikasi dan & pada akhir periode simulasi (tahun 2025) menjadi \\
\hline & Extensifikasi & $212.580 \mathrm{Ha}$. \\
\hline & & $\begin{array}{l}\text { - Produksi gula sebesar 1.105.290 Ton pada tahun } 2011 \\
\text { dan pada tahun } 2025 \text { menjadi 2.061.750 Ton. }\end{array}$ \\
\hline & & - Kebutuhan import menjadi 839.613 Ton. \\
\hline & & $\begin{array}{l}\text { - Harga gula pada tahun } 2025 \mathrm{Rp} 15.024 \text {, hal ini karena } \\
\text { propinsi Jawa Timur masih import gula }\end{array}$ \\
\hline
\end{tabular}


Putra, dkk., Skenario Kebijakan Industri Gula untuk Meningkatkan Ketersediaan Gula..

Saran untuk penelitian selanjutnya adalah memasukkan indikator fabrication/pabrik gula seperti kapasitas mesin giling, lama kinerja mesin, harga tukar dollar, kebijakan regulasi import oleh pemerintah, perhitungan penentuan harga pokok penjualan (HPP) gula dan safety stock.

\section{DAFTAR RUJUKAN}

Andersson, Carina \& Karlsson, Lena. 2001. A System Dynamics Simulation Study of a Software Development Process. CODEN: LUTEDX(TETS-5419)/1-83/(2001)\&local 3. Lund Institute of Technology

Barlas, Y., Multiple tests for validation of system dynamics type of simulation models, European Journal of Operational Research 1989;42:59-87

BPS. Statistic Land Area in East Java (Online) http://aplikasi.deptan.go.id/bdsp/newkom.as p, accessed on 02-02-2013

BPS. Population in East Java (Online). http://www.bps.go.id/tab_sub/view.php?kat $=1 \&$ tabel=1\&daftar $=1 \&$ id_subyek $=12 \&$ not $a b=1$, accessed on 02-02-2013

BPS. Sugar Production in East Java (Online). http://aplikasi.deptan.go.id/bdsp/newkom.as p, accessed on 02-02-2013

Cognizant. 2011. A new framework for safety stock management. Cognizant 20-20 insights

Ellis, R.N., Basford, K.E., Cooper, M., Leslie, J.K., Byth, D.E., 2001. A methodology for analysis of sugarcane productivity trends 1 . Analysis across districts. Aust. J. Agric. Res. 52, 1001-1009

Ferraro, Diego O. \& Rivero, Dario E. \& Ghersa, Claudio M. 2009. An analysis of the factors that influence sugarcane yield in Northern Argentina using classification and regression trees. Field Crops Research 112 (2009) 149-157

Forrester, J..W., (2010). System Dynamics: the Foundation Under Systems Thinking. System Dynamic D-402, 2010

Jensen, A. Paul et all. 1991. Optimal buffer inventories for multistage production systems with failures. European Journal of Operational Research 51 (1991) 313-326

Goldsby, J. Thomas \& Griffis, Stanley E. \& Roath, Anthony S. 2006. Modeling lean, agile, and leagile supply chain strategies. .Journal of business logistics. Vol. 27. No. 1,2006
Javalagi. C.M, Bhushi U.M, 2007, An Overview of Application of System Dynamics Modeling For Analysis of Indian Sugar Industry, proceeding of the 1-4244-15292/07 2007 IEEE

Kemendag. Local sugar price monthly (online). www.kemendag.go.id, accessed on 08-032013

Lawes, R.A., Lawn, R.J., Wegener, M.K., Basford, K.E., 2004. The evaluation of the spatial and temporal stability of sugarcane farm performance based on yield and commercial cane sugar. Aust. J. Agric. Res. $55,335-344$.

Lawes R.A \& Lawn R.J. 2005. Applications of industry information in sugarcane production systems. Field Crops Research 92 (2005) 353-363

Puijman, Roy. 2008. Buffer and inventory management downstream of a cracker: A queuing theory approach. BSc. Industrial

Engineering and Management Science (2008)

Report of the land area sugarcane in Indonesia for the 1967-2011. Departement of agriculture. http://ditjenbun.deptan.go.id/cigraph/index.php/graph/komoditiutama_bar/ 9-Tebu, accessed on 02-02-2013.

Robertson, M.J., Muchow, R.C., Wood, A.W., 1999. A physiological basis for response of sugarcane to drying-off before harvest. Proc. S. Afr. Sugar Technol. Ass. 21, 196202.

Russell, J.S., Wegener, M.K., Valentine, T.R., 1991. Effect of weather variables on C.C.S. at Tully simulated by the AUSCANE model. Proc. Aust. Soc. Sugar Cane Technol. 13, 157-163.

Suara Merdeka. Sugar Production in PTPN IX (media online) http://www.suaramerdeka.com/v1/index.php/read/news/2012/09/28 /131247/Produksi-Gula-PTPN-IX-Capai458.000-Kuintal, diakses 02-02-2013

Sterman, John D. 2000. Business Dynamics Systems Thinking and Modeling for a Complex World. McGraw-Hill Companie, inc.

Simatupang, Pantjar. Justifikasi Dan Metode Penetapan Komoditas Strategis. http://pse.litbang.deptan.go.id/ind/pdffiles/Anjak_20 04_IV_04.pdf(diakses 21-01-2014).

Suryani, Erma. 2005, Pemodelan dan Simulasi, Graha Ilmu.

Swaray, Raymond. 2011. Commodity buffer stock redux: The role of International Cocoa Organization in prices and incomes. Journal of Policy Modeling 33 (2011) 361369 
Putra, dkk., Skenario Kebijakan Industri Gula untuk Meningkatkan Ketersediaan Gula..

\section{Lampiran 1}

Tabel Hasil skenario intensifikasi dan extensifikasi

\begin{tabular}{llllllll}
\hline \multirow{2}{*}{$\begin{array}{l}\text { Time } \\
\text { (Year) }\end{array}$} & $\begin{array}{l}\text { "Total land } \\
\text { area east } \\
\text { java SCN } \\
\text { LE\&I" }\end{array}$ & $\begin{array}{l}\text { Total } \\
\text { land } \\
\text { area }\end{array}$ & $\begin{array}{l}\text { Land } \\
\text { Productivity } \\
\text { SCN I }\end{array}$ & $\begin{array}{l}\text { Land } \\
\text { Productivity }\end{array}$ & $\begin{array}{l}\text { "Sugar } \\
\text { Production } \\
\text { SCN LE\&I" }\end{array}$ & $\begin{array}{l}\text { Sugar } \\
\text { Production } \\
\text { Before SCN } \\
\text { LE \& Int }\end{array}$ & $\begin{array}{l}\text { "Necessary } \\
\text { Import SCN } \\
\text { LE \&" }\end{array}$ \\
\hline 2000 & 148804 & 148804 & 4,73269 & 4,73269 & 704243 & 704243 & 1330000 \\
2001 & 149994 & 149994 & 4,84154 & 4,84154 & 726204 & 726204 & 1312009 \\
2002 & 159444 & 159444 & 5,23806 & 5,23806 & 835178 & 835178 & 1293871,5 \\
2003 & 148921 & 148921 & 5,17049 & 5,17049 & 769994 & 769994 & 1275672,625 \\
2004 & 150078 & 150078 & 6,00294 & 6,00294 & 900907 & 900907 & 1257236,625 \\
2005 & 169326 & 169326 & 6,19203 & 6,19203 & 1048473 & 1048473 & 1238757,625 \\
2006 & 183218 & 183218 & 6,22609 & 6,22609 & 1140735 & 1140735 & 1220250,625 \\
2007 & 204376 & 204376 & 6,56728 & 6,56728 & 1342195 & 1342195 & 1201658,5 \\
2008 & 198627 & 198627 & 6,55809 & 6,55809 & 1302616 & 1302616 & 1183088,625 \\
2009 & 200151 & 200151 & 5,53502 & 5,53502 & 1107843 & 1107843 & 1164298,25 \\
2010 & 200386 & 200386 & 5,09222 & 5,09222 & 1020411 & 1020411 & 1145130,125 \\
2011 & 207410 & & 5,31419 & & 1102215 & & 1125689,5 \\
2012 & 208706 & & 5,54765 & & 1157827 & & 1106143,375 \\
2013 & 210038 & & 5,79135 & & 1216405 & & 1086463,75 \\
2014 & 211406 & & 6,04577 & & 1278111 & & 1066651,5 \\
2015 & 212809 & & 6,31136 & & 1343115 & & 1046707,625 \\
2016 & 214247 & & 6,58862 & & 1411594 & & 1026633,375 \\
2017 & 215721 & & 6,87805 & & 1483740 & & 1006430,188 \\
2018 & 217229 & & 7,18021 & & 1559753 & & 986099,5625 \\
2019 & 218773 & & 7,49563 & & 1639843 & & 965643,1875 \\
2020 & 220352 & & 7,82492 & & 1724237 & & 945063 \\
2021 & 221966 & & 8,16866 & & 1813170 & & 924361,0625 \\
2022 & 223617 & & 8,52751 & & 1906893 & & 903539,625 \\
2023 & 225303 & & 8,90213 & & 2005672 & & 882601,25 \\
2024 & 227025 & & 9,2932 & & 2109788 & & 861548,75 \\
2025 & 228784 & & 9,70145 & & 2219537 & & 840385,0625 \\
\hline
\end{tabular}

